\title{
Comparative lung toxicity of engineered nanomaterials utilizing in vitro, ex vivo and in vivo approaches
}

\author{
Yong Ho Kim ${ }^{1}$, Elizabeth Boykin ${ }^{2}$, Tina Stevens ${ }^{3}$, Katelyn Lavrich ${ }^{1}$ and M lan Gilmour ${ }^{2 *}$
}

\begin{abstract}
Background: Although engineered nanomaterials (ENM) are currently regulated either in the context of a new chemical, or as a new use of an existing chemical, hazard assessment is still to a large extent reliant on information from historical toxicity studies of the parent compound, and may not take into account special properties related to the small size and high surface area of ENM. While it is important to properly screen and predict the potential toxicity of ENM, there is also concern that current toxicity tests will require even heavier use of experimental animals, and reliable alternatives should be developed and validated. Here we assessed the comparative respiratory toxicity of ENM in three different methods which employed in vivo, in vitro and ex vivo toxicity testing approaches.

Methods: Toxicity of five ENM ( $\mathrm{SiO}_{2}$ (10), $\mathrm{CeO}_{2}$ (23), $\mathrm{CeO}_{2}$ (88), $\mathrm{TiO}_{2}$ (10), and $\mathrm{TiO}_{2}$ (200); parentheses indicate average ENM diameter in $\mathrm{nm}$ ) were tested in this study. CD-1 mice were exposed to the ENM by oropharyngeal aspiration at a dose of $100 \mu \mathrm{g}$. Mouse lung tissue slices and alveolar macrophages were also exposed to the ENM at concentrations of 22-132 and 3.1-100 $\mu \mathrm{g} / \mathrm{mL}$, respectively. Biomarkers of lung injury and inflammation were assessed at 4 and/or $24 \mathrm{hr}$ post-exposure.
\end{abstract}

Results: Small-sized ENM ( $\mathrm{SiO}_{2}(10), \mathrm{CeO}_{2}(23)$, but not $\left.\mathrm{TiO}_{2}(10)\right)$ significantly elicited pro-inflammatory responses in mice (in vivo), suggesting that the observed toxicity in the lungs was dependent on size and chemical composition. Similarly, $\mathrm{SiO}_{2}$ (10) and/or $\mathrm{CeO}_{2}$ (23) were also more toxic in the lung tissue slices (ex vivo) and alveolar macrophages (in vitro) compared to other ENM. A similar pattern of inflammatory response (e.g., interleukin-6) was observed in both ex vivo and in vitro when a dose metric based on cell surface area $\left(\mu \mathrm{g} / \mathrm{cm}^{2}\right)$, but not culture medium volume $(\mu \mathrm{g} / \mathrm{mL})$ was employed.

Conclusion: Exposure to ENM induced acute lung inflammatory effects in a size- and chemical composition-dependent manner. The cell culture and lung slice techniques provided similar profiles of effect and help bridge the gap in our understanding of in vivo, ex vivo, and in vitro toxicity outcomes.

Keywords: Engineered nanomaterials, Lung toxicity, Alternative toxicity testing

\section{Background}

It is well recognized that nanotechnology has been rapidly growing and advancing over the past 10 years, and will continue to expand in numerous market sectors $[1,2]$. The advances in nanotechnology, however are accompanied by a need for better understanding of the exposure and toxicity of engineered nanomaterials (ENM) across their life-cycle. Moreover, the enormously diverse

\footnotetext{
* Correspondence: gilmour.ian@epa.gov

EEnvironmental Public Health Division, National Health and Environmental Effects Research Laboratory, United States Environmental Protection Agency, Research Triangle Park, NC, USA

Full list of author information is available at the end of the article
}

and applications of ENM (e.g., shapes, sizes, chemical and surface characteristics) are likely to result in a broad array of exposures and potentially adverse health outcomes. Thus, methods to evaluate and predict the toxicity of ENM are of considerable importance [3]. In particular, more information is needed on the interactions of ENM with lung tissue, since inhalation is a common exposure route and can also lead to potential systemic toxicity [1]. There is already substantial epidemiologic and toxicological evidence that inhaled ENM cause pulmonary effects (e.g., inflammation and/or edema) and/or extrapulmonary or systemic effects (e.g., thrombosis, dysrhythmias, and 
myocardial infarction) [4-7]. In general, nanotoxicology studies of the respiratory tract are performed with in vivo (e.g., mice and rats) or in vitro (e.g., airway/alveolar epithelial cells, macrophages, and dendritic cells) models. Because of the inherent anatomical complexity of the intact lung which is comprised of about 40 different cell types interpretation of toxicity of ENM in in vitro cell culture models is limited as they do not reflect the complex cell-cell contacts and cell-matrix interactions in the tissue. Moreover, despite the need for studying the toxicity of ENM in vivo, there is a growing concern that broad toxicity testing will increase the number of animals required. Therefore, developing credible alternative testing methods predictive of in vivo ENM toxicity are essential to screen potential hazards and health risks associated with inhalation exposures to these novel materials [2].

Here, we investigated pulmonary toxicity of five ENM: one silicon dioxide $\left(\mathrm{SiO}_{2}\right)$, two cerium oxide $\left(\mathrm{CeO}_{2}\right)$, and two titanium dioxide $\left(\mathrm{TiO}_{2}\right)$ nanomaterials with different primary diameters. $\mathrm{SiO}_{2}, \mathrm{CeO}_{2}$, and $\mathrm{TiO}_{2}$ nanomaterials are already widely used in industrial processes and consumer products. $\mathrm{CeO}_{2}$ and $\mathrm{TiO}_{2}$ nanomaterials are the most abundantly produced metal oxide nanomaterials in the U.S. [8] and have been independently tested for adverse health effects in vitro and in vivo, but not in the same study design $[9,10] . \mathrm{CeO}_{2}$ nanomaterials are of interest because despite having the same crystalline form as the parent compound, the nano-sized material causes more oxidative stress as a result of subtle changes in their surface chemistry $[11,12]$. $\mathrm{SiO}_{2}$ nanomaterials (particularly the amorphous form), have also recently received attention in biomedical applications, yet their toxicity is not fully understood [13]. In the present study, we conducted acute toxicity tests in mice (in vivo), mouse lung tissue slices (ex vivo), and mouse alveolar macrophages (in vitro) to extrapolate, and compare the results between ex vivo or in vitro to in vivo toxicity testing approaches. Lung tissue slices have shown to preserve almost all cell types and interactions with the microenvironment (i.e., cell-cell or cell-matrix interactions), thus providing the most in vivolike physiologically relevant response. Of all the different types of lung cells, alveolar macrophages are considered to be one of the first lines of a defense against inhaled particles and are primarily responsible for producing proinflammatory mediators [14]. The specific aims of this study were to determine the pulmonary toxicity and proinflammatory potential of ENM in mice, and compare these effects with the use of ex vivo lung slice and in vitro cell-based toxicity testing systems.

\section{Results}

Particle size distributions of ENM

Hydrodynamic diameters of ENM in the various solutions used in this study were determined by dynamic light scattering (Table 1). Diameters of all ENM suspended in water were greater than the specifications provided by the manufacturer, and were even larger when the materials were suspended in culture media. Of all the ENM studied, $\mathrm{TiO}_{2}$ (10) and $\mathrm{SiO}_{2}$ (10) were the most highly agglomerated. Since this clumping behavior controls the density of the ENM agglomerates in suspensions, we estimated the agglomerate density and presented the results in Table $1 . \mathrm{SiO}_{2}$ (10) had the lowest agglomeration density in any solution, indicating that this material was most likely to remain suspended in the solutions and less likely to interact with the cells. Agglomerated $\mathrm{TiO}_{2}$ (200), on the other hand had the highest density which would promote settling and a greater potential to come in contact with the cells on the plate bottom.

\section{Pulmonary inflammation responses in vivo}

We monitored concentrations of lactate dehydrogenase (LDH) released into bronchoalveolar lavage fluid (BALF) at $4 \mathrm{hr}$ and $24 \mathrm{hr}$ post-exposure as a biomarker for lung cell injury. None of the ENM, except for $\mathrm{CeO}_{2}$ (88) (at $24 \mathrm{hr}$ post-exposure), significantly increased the concentrations of LDH at any time point compared with saline control groups (Figure 1A). N-acetyl- $\beta$-D-glucosaminidase (NAG) and $\gamma$-glutamyl transferase (GGT) as biomarkers for lysosomal enzyme and oxidative stress, respectively, were also assessed and were unchanged for any of the ENM (data not shown). Concentrations of albumin and total protein in BALF from the $\mathrm{CeO}_{2}$ (23)-exposed groups were significantly increased at $4 \mathrm{hr}$ and $24 \mathrm{hr}$ postexposure compared with saline-exposed groups, indicating that this material caused lung edema (Figure $1 \mathrm{~B}$ and $\mathrm{C}$ ). As a positive control, LPS increased LDH, albumin, and protein as expected, but did not affect NAG or GGT. The size- and composition-dependent toxicity of ENM was also seen in pulmonary inflammatory cells at $4 \mathrm{hr}$ and $24 \mathrm{hr}$ post-exposure (Figure 2). The $\mathrm{CeO}_{2}$ (23)-exposure groups significantly increased the number of neutrophils (18\% and $34 \%$ at 4 hrs and 24 hrs, respectively), compared with saline controls. While LPS-exposure groups induced an even stronger neutrophil influx, no other ENM caused significant changes in the neutrophil number. The number of macrophages in BALF was unchanged by any treatment.

Concentrations of pro-inflammatory cytokines (interleukin-6 (IL-6), macrophage inhibitory protein-2 (MIP-2), and tumor necrosis factor- $\alpha$ (TNF- $\alpha)$ ) were then monitored in BALF at both time-points (Figure 3). $\mathrm{CeO}_{2}$ (23) significantly increased the concentrations of all three cytokines at $4 \mathrm{hr}$ post-exposure compared with saline control groups. $\mathrm{SiO}_{2}$ (10) significantly increased the concentrations of IL- 6 and MIP-2 at 4 hr post-exposure, while $\mathrm{TiO}_{2}$ (10) but not the $\mathrm{TiO}_{2}$ (200) only increased the concentration of MIP-2. These data indicate that the small-sized 
Table 1 Physicochemical properties of engineered nanomaterials (ENM)

\begin{tabular}{|c|c|c|c|c|c|c|c|c|c|c|c|c|}
\hline \multirow[t]{2}{*}{ Chemical } & \multirow[t]{2}{*}{ ID } & \multirow{2}{*}{$\begin{array}{l}\text { Primary } \\
\text { diameter }^{\mathrm{a}} \\
(\mathrm{nm})\end{array}$} & \multicolumn{4}{|c|}{ Hydrodynamic diameter $(\mathrm{nm})$} & \multirow{2}{*}{$\begin{array}{l}\text { Surface area } \\
\left(\mathrm{m}^{2} / \mathrm{g}\right)\end{array}$} & \multirow{2}{*}{$\begin{array}{l}\text { Raw density } \\
\left(\mathrm{g} / \mathrm{cm}^{3}\right)\end{array}$} & \multirow{2}{*}{$\begin{array}{l}\text { Equivalent } \\
\text { primary } \\
\text { diameter }(\mathrm{nm})\end{array}$} & \multicolumn{2}{|c|}{ Agglomerate density ${ }^{\mathrm{g}}\left(\mathrm{g} / \mathrm{cm}^{3}\right)$} & \multirow{2}{*}{$\begin{array}{l}\text { Crystal } \\
\text { form }\end{array}$} \\
\hline & & & Water & $\begin{array}{l}\text { Saline } \\
\text { (in vivo) }\end{array}$ & $\begin{array}{l}\mathrm{CM}^{\mathrm{c}} \\
\text { (ex vivo) }\end{array}$ & $\begin{array}{l}\mathrm{CM}^{\mathrm{C}} \\
\text { (in vitro) }\end{array}$ & & & & $\begin{array}{l}\mathrm{CM}^{\mathrm{c}} \\
(\text { ex vivo) }\end{array}$ & $\begin{array}{l}\mathrm{CM}^{\mathrm{c}} \\
\text { (in vitro) }\end{array}$ & \\
\hline $\mathrm{SiO}_{2}$ & $\mathrm{SiO}_{2}(10)$ & $5-15^{a}$ & $401 \pm 13$ & $574 \pm 96$ & $458 \pm 66$ & $342 \pm 44$ & $590-690^{a}$ & 2.65 & 3.54 & $1.06 \pm 0.01$ & $1.07 \pm 0.01$ & Amorphou \\
\hline $\mathrm{CeO}_{2}$ & $\mathrm{CeO}_{2}(23)$ & $15-30^{\mathrm{a}}$ & $131 \pm 55$ & $269 \pm 91$ & $796 \pm 46$ & $432 \pm 133$ & $30-50^{a}$ & 7.22 & 20.79 & $1.49 \pm 0.03$ & $1.88 \pm 0.45$ & Cerianite \\
\hline $\mathrm{CeO}_{2}$ & $\mathrm{CeO}_{2}(88)$ & $70-105^{\mathrm{a}}$ & $162 \pm 60$ & $239 \pm 52$ & $500 \pm 38$ & $220 \pm 31$ & $8-12^{\mathrm{a}}$ & 7.22 & 83.16 & $2.78 \pm 0.18$ & $4.23 \pm 0.58$ & Cerianite \\
\hline $\mathrm{TiO}_{2}$ & $\mathrm{TiO}_{2}(10)$ & $10^{\mathrm{a}}$ & $402 \pm 16$ & $739 \pm 10$ & $645 \pm 3$ & $660 \pm 62$ & $100-130^{\mathrm{a}}$ & 3.90 & 12.33 & $1.19 \pm 0.00$ & $1.19 \pm 0.02$ & Anatase \\
\hline $\mathrm{TiO}_{2}$ & $\mathrm{TiO}_{2}(200)$ & $200^{\mathrm{a}}$ & $387 \pm 12$ & $690 \pm 29$ & $493 \pm 6$ & $417 \pm 22$ & $6.99^{d}$ & 3.90 & 202.92 & $2.65 \pm 0.03$ & $2.86 \pm 0.12$ & Anatase \\
\hline
\end{tabular}

aprovided by the manufacturer.

determined by dynamic light scattering and expressed as mean \pm SEM of multiple measurements.

CM: culture medium.

obtained from Sanders et al. [15]

obtained from the CRC Handbook of Chemistry and Physics [16].

${ }^{f}$ calculated from equivalent primary diameter $=6 /(S S A \times \rho)[17,18]$, where $S S A$ is specific surface area, and $\rho$ is raw nanomaterial density.

${ }^{9}$ calculated from the Sterling equation [19], agglomerate density $=\left(1-\left(1-\left(d_{H} / d_{E q}\right)^{D F-3}\right)\right) \rho+\left(1-\left(d_{H} / d_{E q}\right)^{D F-3}\right) \rho_{\text {media }}$, where $d_{H}$ is hydrodynamic diameter, $d_{E q}$ is equivalent primary diameter, $D F$ is theoretical fractal dimension (assuming $D F=2.3[20]), \rho$ is raw nanomaterial density, and $\rho_{\text {media }}$ is media density (assuming $\rho_{\text {media }}=1 \mathrm{~g} / \mathrm{cm}^{3}$ ). 


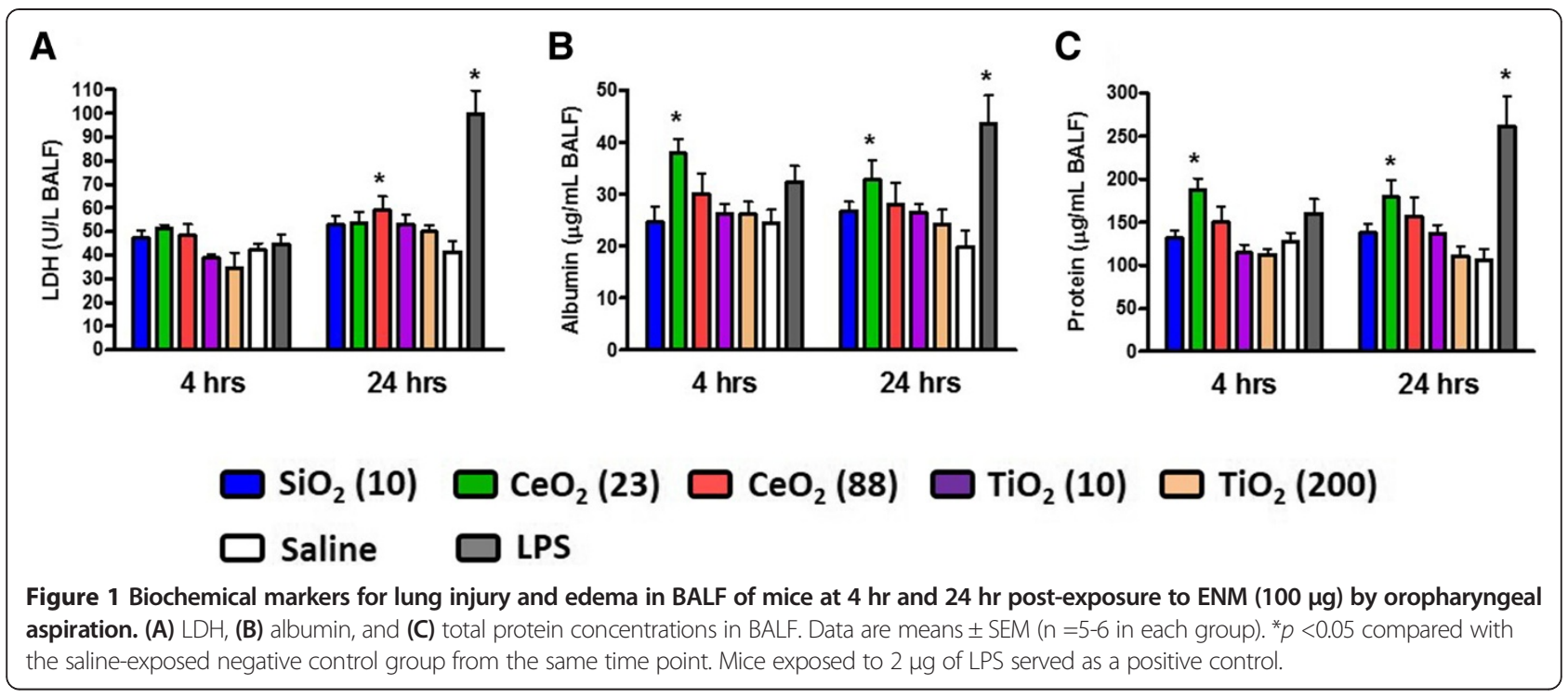

ENM induced more acute lung inflammation than their larger counterparts, and that chemical composition of ENM was a more important determinant than their size. Based on the cytokine response results, toxicity ranking of ENM approximated $\mathrm{CeO}_{2}(23) \approx \mathrm{SiO}_{2}(10)>\mathrm{TiO}_{2}(10)>$ $\mathrm{CeO}_{2}(88)>\mathrm{TiO}_{2}$ (200). At $24 \mathrm{hr}$ post-exposure, the cytokine concentrations decreased to saline control values except for $\mathrm{CeO}_{2}$ (23) which maintained elevated levels of IL- 6 and TNF- $\alpha$. Interestingly, the inflammation was not related to uptake of ENM in lung macrophages. The less active $\mathrm{TiO}_{2}$ (10) and $\mathrm{TiO}_{2}$ (200) were avidly taken up by lung macrophages at both time points compared with other ENM (Additional file 1: Figure S1). Finally, there were no significant changes in circulating white blood cells, red blood cells (RBCs) or RBC indices between the ENM-exposed mice and saline controls (data not shown).

\section{Pulmonary inflammation responses ex vivo and in vitro}

LDH, GGT, and NAG concentrations in the supernatants from the lung tissue slices at $24 \mathrm{hr}$ post-exposure were unchanged at any of the concentrations tested (data not shown). Only the $\mathrm{SiO}_{2}$ (10) at the highest concentration $(132 \mu \mathrm{g} / \mathrm{mL})$ significantly increased the concentrations of IL-6 and MIP-2 compared with negative controls (Figure 4).

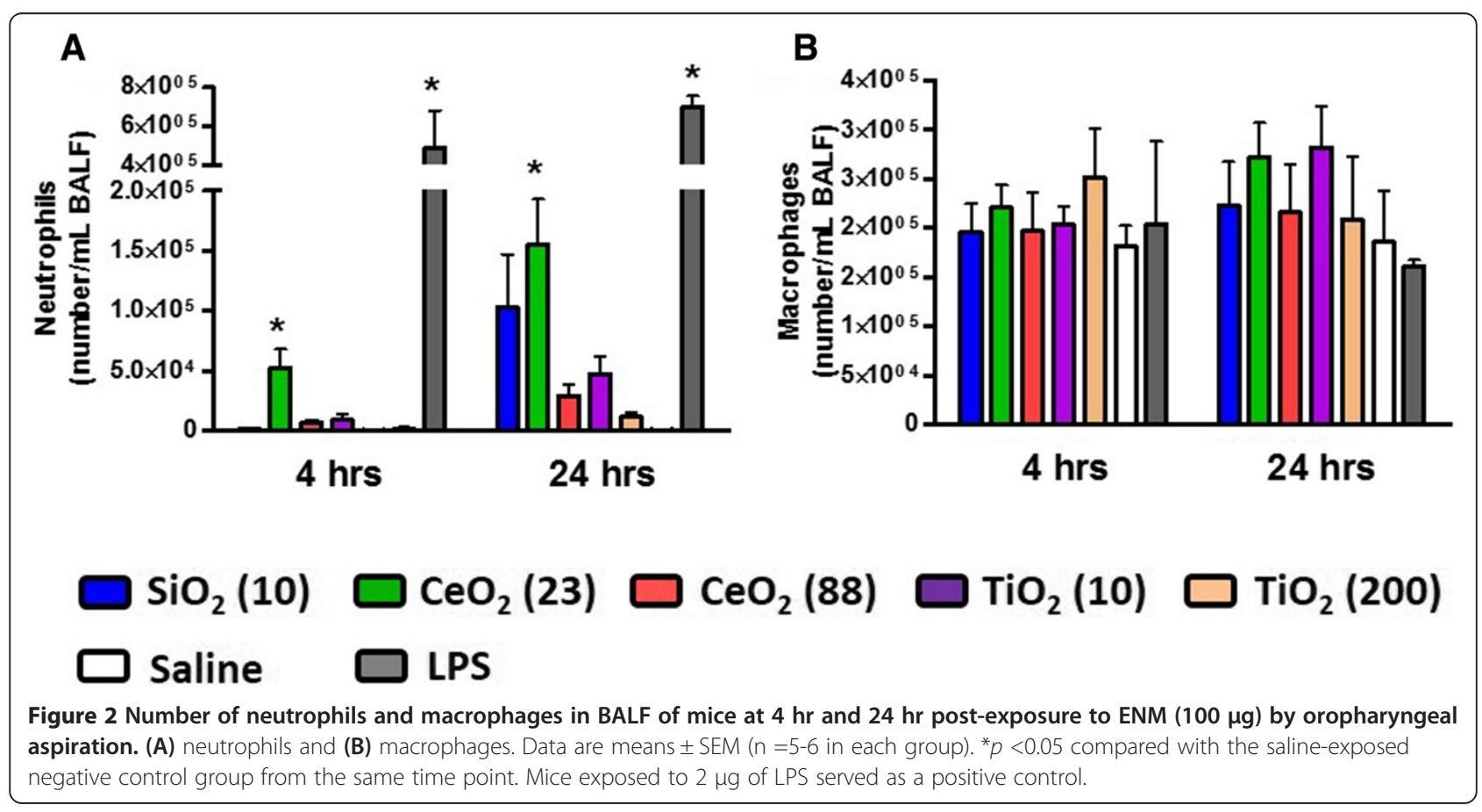




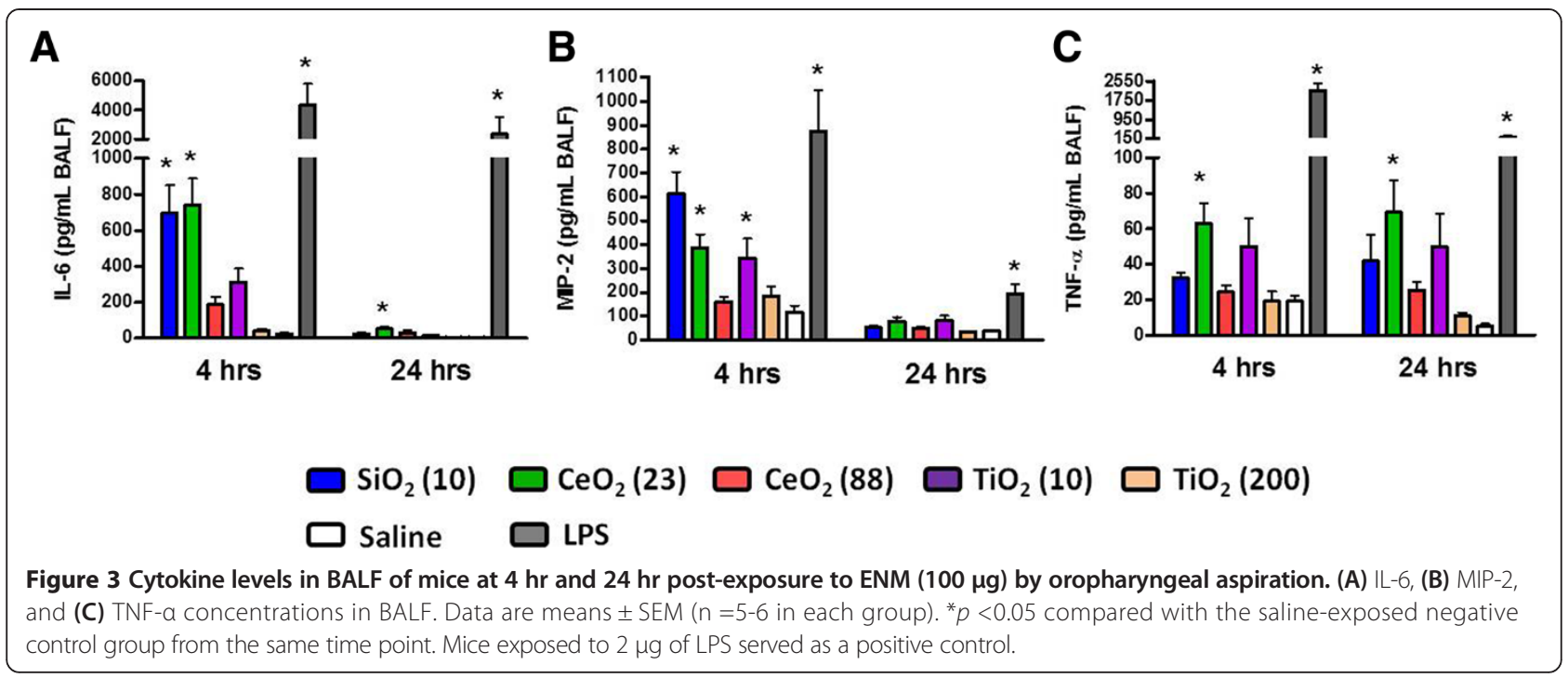

$\mathrm{CeO}_{2}$ (23) also had increased IL-6 concentration but this was not statistically significant.

Assessment of the cell culture supernatant from ENMexposed $\mathrm{MH}-\mathrm{S}$ cells at $24 \mathrm{hr}$ post-exposure revealed that all ENM increased the LDH release in a dose-dependent manner (Figure 5A). $\mathrm{SiO}_{2}$ (10) and $\mathrm{TiO}_{2}$ (10 and 200) appeared to be more and less cytotoxic, respectively, however no apparent size-dependent effects (on cell membrane integrity) were observed. Half-maximal effective concentrations $\left(\mathrm{EC}_{50}\right)$ for the cell membrane integrity of $\mathrm{SiO}_{2}$ (10), $\mathrm{CeO}_{2}$ (23), $\mathrm{CeO}_{2}$ (88), $\mathrm{TiO}_{2}$ (10), and $\mathrm{TiO}_{2}$ (200) were approximately $100,295,141,330$, and $384 \mu \mathrm{g} /$ $\mathrm{mL}$, respectively. Cell viability based on the metabolic activity of mitochondria was assessed at $24 \mathrm{hr}$ postexposure (Figure 5B). Similar to the LDH analysis data, we also observed dose-dependent effects of ENM. $\mathrm{EC}_{50}$ for the cell viability of $\mathrm{SiO}_{2}(10), \mathrm{CeO}_{2}(23), \mathrm{CeO}_{2}(88), \mathrm{TiO}_{2}$ (10), and $\mathrm{TiO}_{2}$ (200) were approximately $13,18,55,30$, and $77 \mu \mathrm{g} / \mathrm{mL}$, respectively (Additional file 2: Figure S2). Thus, toxicity ranking of $\mathrm{ENM}$ based on the $\mathrm{EC}_{50}$ for viability was in the order of $\mathrm{SiO}_{2}(10)>\mathrm{CeO}_{2}(23)>\mathrm{TiO}_{2}$ (10) $>\mathrm{CeO}_{2}(88)>\mathrm{TiO}_{2}$ (200). Because the $\mathrm{EC}_{50}$ was much higher for $\mathrm{LDH}$, this would indicate that the mitochondrial function was more sensitive to ENM exposure than cell membrane integrity. We also measured cell proliferation based on DNA content at $24 \mathrm{hr}$ post-exposure and found

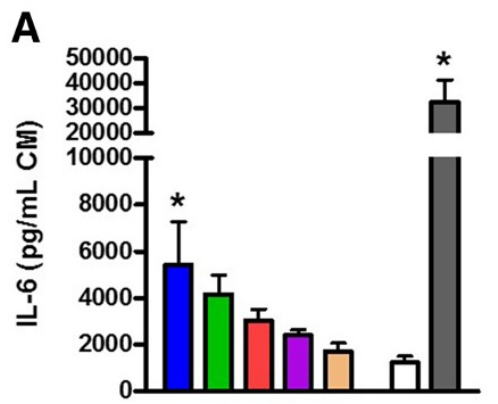

B

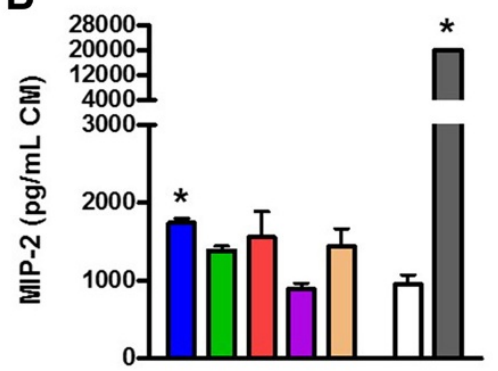

C

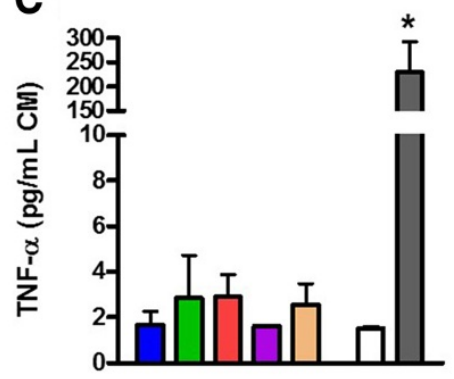

$\mathrm{SiO}_{2}(10)$

$\mathrm{CeO}_{2}(23)$

$\mathrm{CeO}_{2}(88)$

$\mathrm{TiO}_{2}(10)$

$\mathrm{TiO}_{2}(200)$

Culture Medium (CM)

LPS

Figure 4 Cytokine levels in lung tissue slices at $24 \mathrm{hr}$ post-exposure to ENM (132 $\mu \mathrm{g} / \mathrm{mL})$. (A) IL-6, (B) MIP-2, and (C) TNF-a concentrations in the culture medium (CM) from the lung tissue slices. Data are means \pm SEM ( $n=3$ in each group). ${ }^{*} p<0.05$ compared with CM-exposed negative control group. Lung tissue slices exposed to $87 \mathrm{ng} / \mathrm{mL}$ of LPS served as a positive control. 


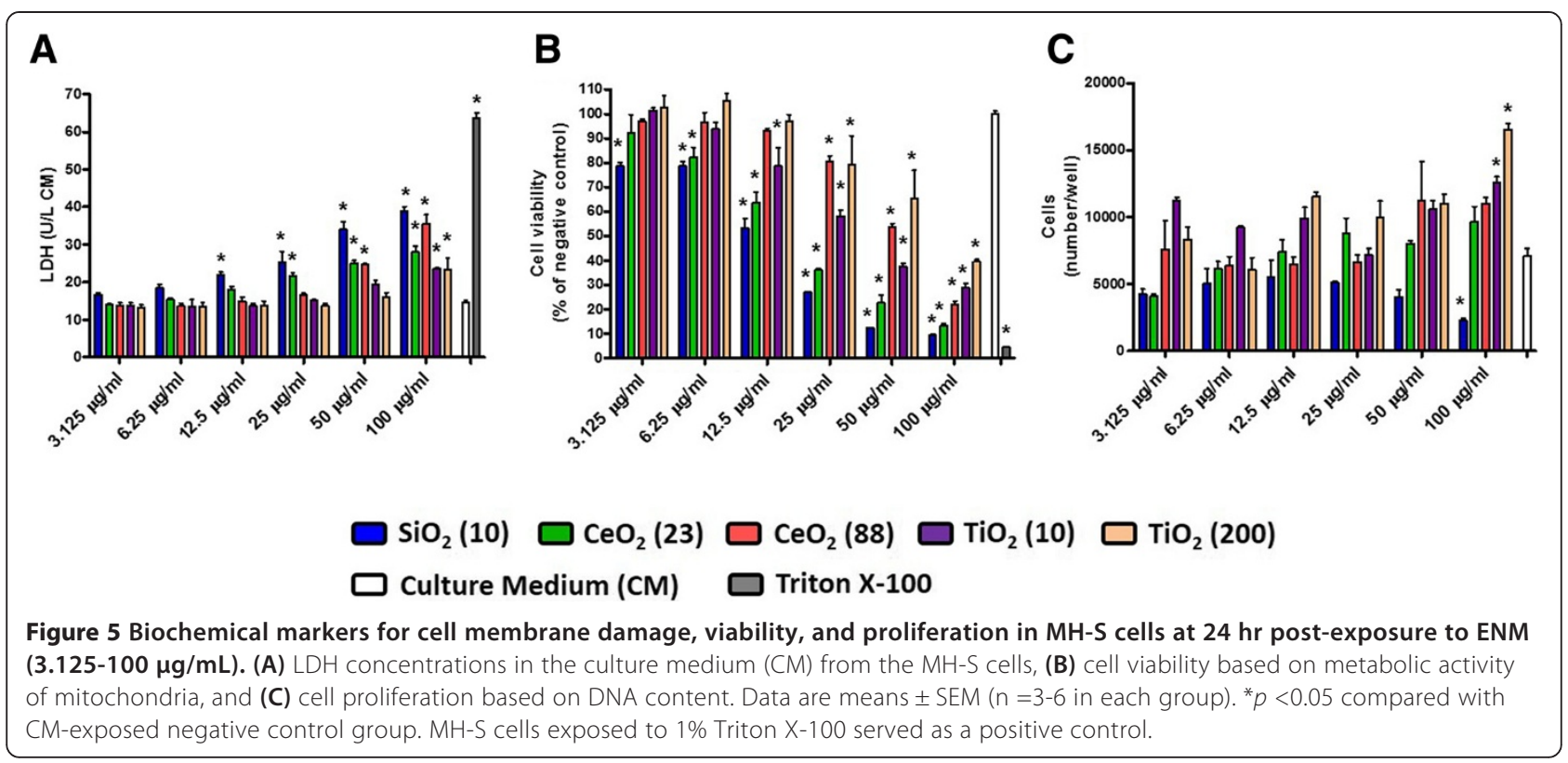

that cell numbers did not significantly change in any of the ENM-exposed groups except at the high concentration exposure (Figure $5 \mathrm{C}$ ). At $100 \mu \mathrm{g} / \mathrm{mL}$ concentration, $\mathrm{SiO}_{2}$ (10) significantly decreased $\mathrm{MH}-\mathrm{S}$ cell numbers, while $\mathrm{TiO}_{2}$ (10) and $\mathrm{TiO}_{2}$ (200) significantly increased the cell numbers. Concentrations of pro-inflammatory cytokine, IL-6, in MH-S cells were measured at $24 \mathrm{hr}$ post-exposure (Figure 6). $\mathrm{SiO}_{2}$ (10) induced more IL-6 production than other ENM which was in line with the IL-6 lung tissue slice response. To provide a more realistic comparison, we converted the nominal mass media concentration (i.e., $\mu \mathrm{g} / \mathrm{mL}$ ) to mass per unit cell (or tissue) surface area (i.e., $\mu \mathrm{g} / \mathrm{cm}^{2}$ ) because lung tissue slices have a larger 3D surface area than the MH-S cells. Taking this into account the exposure dose of $132 \mu \mathrm{g} / \mathrm{mL}$ to the lung slice resulted in a dose of $4.7 \mu \mathrm{g} / \mathrm{cm}^{2}$. Therefore, the IL-6 responses in MH-S cells exposed to $12.5 \mu \mathrm{g} / \mathrm{mL}$ concentration (equivalent to $4.2 \mu \mathrm{g} / \mathrm{cm}^{2}$ ) was comparable to those in the lung tissue slices exposed to $132 \mu \mathrm{g} /$ $\mathrm{mL}$ concentration (see the Materials and Methods section for a more detailed calculation).

\section{Discussion}

While much work is being done to better understand the potential toxic effects of ENM on human health, it is still not clear which physico-chemical parameters of ENM are
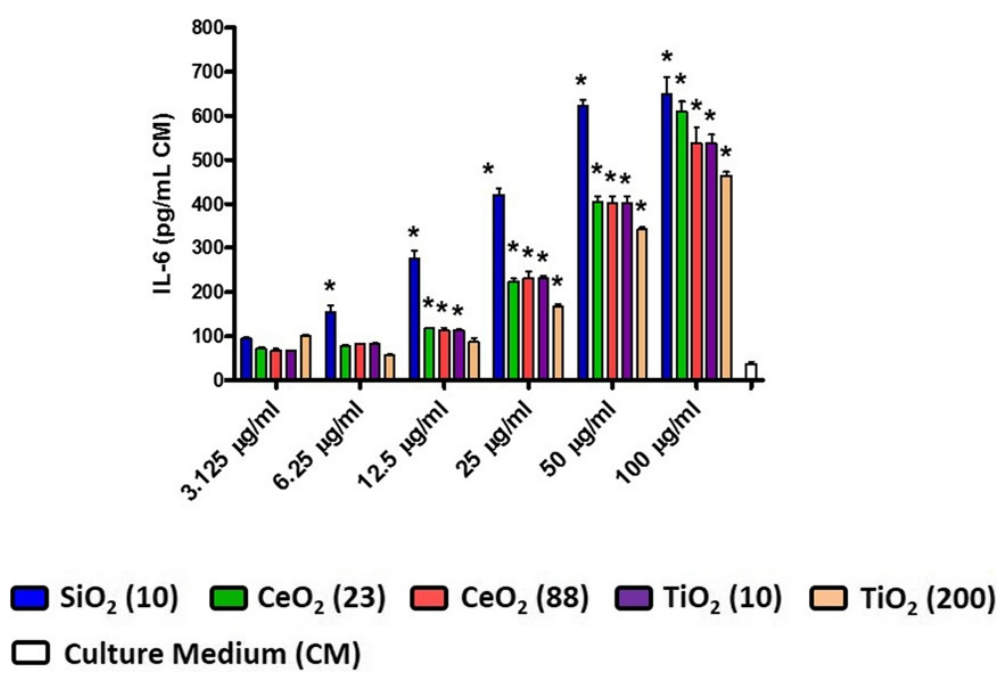

Figure $\mathbf{6}$ Cytokine level in MH-S cells at $\mathbf{2 4} \mathbf{~ h r}$ post-exposure to ENM (3.125-100 $\boldsymbol{\mu g} / \mathbf{m L})$. Data are means $\pm S E M\left(n=3\right.$ in each group). ${ }^{*} p<0.05$ compared with CM-exposed negative control group. 
most important. Moreover, assessing (or screening) the toxic potential of emerging ENM is likely to increase the numbers of animals required, unless alternative methods are available that consistently reflect the in vivo biological effects. Here we utilized three different toxicity testing methods (mice, mouse lung tissue slices, and alveolar macrophages) to investigate the comparative toxicity of five $\mathrm{ENM}\left(\mathrm{SiO}_{2}(10), \mathrm{CeO}_{2}(23), \mathrm{CeO}_{2}(88), \mathrm{TiO}_{2}\right.$ (10), and $\mathrm{TiO}_{2}$ (200)) and determine if the latter two techniques could predict effects seen in animals. We found, in all three different toxicity testing methods, that $\mathrm{SiO}_{2}$ (10) and/or $\mathrm{CeO}_{2}$ (23) had the highest activity on the basis of pro-inflammatory cytokine production. Importantly the mouse lung tissue slices and alveolar macrophages exhibited similar cytokine responses to the distinct ENM when the exposure dose metric was based on cell surface area.

\section{Size- and chemical composition-dependent lung toxicity of ENM in mice}

Numerous studies of nanotoxicology have shown that toxicity of ENM is strongly influenced by two factors: 1) chemical toxicity based on the chemical composition of ENM, and 2) cellular stress caused by the physical properties of ENM [9]. In line with published reports, it was evident that only the smaller-sized ENM caused significant inflammatory effects on mouse lungs, and that the chemical composition was important since stronger effects were noted in $\mathrm{SiO}_{2}$ (10) and $\mathrm{CeO}_{2}$ (23) but not $\mathrm{TiO}_{2}$ (10). Interestingly $\mathrm{TiO}_{2}$ lung macrophage uptake was higher than the other ENM, despite displaying lower toxicity suggesting that the observed inflammatory responses were not dependent on phagocytosis. In support of this, a similar study demonstrated that nanomaterial toxicity was not correlated with particle uptake in the cells [21].

Although further studies are needed to understand the mechanism underlying lung toxicity of ENM, the data also suggest that there was no clear relationship between lung toxicity and degree of ENM agglomeration (i.e., hydrodynamic diameters). Agglomerates of ENM form in biological fluids by loose binding (e.g., van der Waals force) while primary diameters, and not hydrodynamic diameters influence toxicity. In support of this, other researchers have reported that nanoparticle trafficking across lung epithelial cells was correlated with primary diameters and not the hydrodynamic diameters of the agglomerated nanoparticles [22].

Numerous studies have reported that ENM of various crystalline forms and solubility cause varying degrees of lung injury and inflammation. It is generally accepted that insoluble ENM are far less active in producing cellular damage or injury as compared to (partially) soluble ENM of similar size [23-25], although insoluble ENM have the potential to remain in the lungs and other organs for a long. It also should be noted that while insoluble ENM may not be potent enough to cause cell damage, crystallinity of the ENM (e.g., amorphous or crystalline) might contribute to other toxicological properties $[10,26]$. In addition, insoluble ENM may cause oxidative stress and lung inflammation depending on their conduction band energy levels [27]. The ENM used in this study $\left(\mathrm{SiO}_{2}, \mathrm{CeO}_{2}\right.$, and $\left.\mathrm{TiO}_{2}\right)$ were insoluble (or poorly soluble) in biological fluids and considered not to release free ions from the nanomaterials to the tissue or cells. Here, the cytokine responses induced by $\mathrm{SiO}_{2}$ (10) and $\mathrm{CeO}_{2}$ (23) were evident in mice at $4 \mathrm{hr}$ post-exposure but receded to control levels at $24 \mathrm{hrs}$, indicating that the inflammatory response was transient. Others have reported sustained pro-inflammatory cytokine levels at 24 hrs after exposure to $\mathrm{SiO}_{2}$ (amorphous and $14 \mathrm{~nm}$ ) albeit with $50 \mathrm{mg} / \mathrm{kg}$ which is $\sim 15$ times higher than the concentration used here [28]. While lung toxicity of $\mathrm{SiO}_{2}$ nanomaterials has been extensively studied [26], there are only a few reports of lung toxicity of $\mathrm{CeO}_{2}$ nanomaterials [9,29-32]. Moreover, these studies have mainly focused on long-term toxicity in mice or rats, demonstrating that intratracheal instillation or inhalation of $\mathrm{CeO}_{2}$ nanomaterials led to severe chronic lung inflammation for up to 28 day post-exposure. Although our findings were limited to the $24 \mathrm{hr}$ time-course, we cannot rule out the possibility of further chronic inflammatory responses, particularly in light of human case studies which report development of lung disease in workers after repeated long-term exposure of $\mathrm{CeO}_{2}$ [33,34]. Similarly, our results showed that $\mathrm{TiO}_{2}$ nanomaterials did not cause significant lung inflammation in mice, consistent with recently published $\mathrm{TiO}_{2}$ toxicity findings performed through multiple interlaboratory comparisons [35].

\section{Comparing lung toxicity testing in mice to its alternatives} Efforts to reduce the number of animals in toxicity testing have resulted in the development of numerous ex vivo and in vitro toxicity test methods but the results are still conflicting. This inconsistency could be due to the fact that there are 1) a lack of overall consensus on the relevant dose metric for in vivo and ex vivo/in vitro studies and 2) inherent limitations to most in vitro models such as a lack of complex cell-cell interactions [36]. Here, the mouse lung tissue slices (ex vivo) and $\mathrm{MH}-\mathrm{S}$ cells (in vitro) displayed a similar pattern of cytokine response on the basis of the mass per unit surface area of cell or tissue $\left(\mu \mathrm{g} / \mathrm{cm}^{2}\right)$ but not per unit volume of culture medium $(\mu \mathrm{g} / \mathrm{mL})$, suggesting that cell surface area should be considered in in vitro dosimetry when comparing toxicity endpoints from different systems.

It is well documented that nanomaterials form agglomerates in suspension and their fate (or behavior) is governed by different mass transport properties (sedimentation and/ 
or diffusion), leading to differential exposures of nanomaterials to cells $[17,18,20]$. The nominal mass media concentration $(\mu \mathrm{g} / \mathrm{mL})$ in submerged cell-culture conditions assumes that the suspended nanomaterials are completely deposited on the cell surface which may not be always true for all nanomaterials in suspension and may result in misinterpretation of biological response data [37]. In the present study the density of agglomerated ENM in suspension (which influences delivered dose) was associated with the resultant cellular responses ex vivo and in vitro $[17,18,20]$. Notably, if the agglomerate density approached the density of the culture medium, the nanomaterials were more likely to remain suspended in the medium (i.e., low delivered dose), leading to a reduced exposure and diminution of biological responses to the nanomaterials $[17,18]$. In this regard, since the agglomerate densities of $\mathrm{SiO}_{2}$ (10), $\mathrm{CeO}_{2}(23)$ and $\mathrm{TiO}_{2}(10)$ ex vivo and in vitro were closer to the culture media compared to other ENM, it is likely that the toxic effects were underestimated. In other words, the cytokine responses ex vivo and in vitro would be expected to increase even more if the cells were exposed to the same delivered dose. Therefore, considering the behavior of ENM agglomerates in submerged cell culture systems (ex vivo or in vitro) may reduce the disparity between in vitro and in vivo nanotoxicology outcomes. However, there are limitations to be considered when interpreting in vitro cellular responses based on agglomerate density. If ENM are soluble in culture media, their agglomerate density will change over time. Moreover, as described above, in the case of in vitro ENM toxicity tests, agglomerations may result in an underestimation of toxicity outcomes (or ranking), while in the case of in vivo ENM toxicity tests (via intratracheal instillation or oropharyngeal aspiration technique), agglomeration may cause an overestimation of toxicity outcomes (or ranking) [38]. It is also worth noting that the agglomeration associated with ability of ENM to absorb biological components (e.g., ions, salts, and proteins) in the in vitro and in vivo system may differently overshadow ENM properties (e.g., chemistry and surface charge), leading to the inconsistent results (in vitro versus in vivo) [39].

As aforementioned, one of the major challenges faced in cell-based in vitro models is that intact lungs are comprised of about 40 different cell types, and in vitro models cannot wholly reflect the microenvironment of cell-cell and cell-matrix interactions. Here we utilized the lung tissue slice model which preserves the lung architecture with nearly all cell types. We have previously reported that mouse lung tissue slices incubated with size fractionated particulate matter from a wildfire event displayed similar cytokine responses to those observed in mice [40]. In line with this finding, the lung tissue slice system also showed similar pro-inflammatory responses to ENM as those seen in mice (i.e., pro-inflammatory effects of $\mathrm{SiO}_{2}$ (10) and $\mathrm{CeO}_{2}$ (23) but not $\mathrm{TiO}_{2}$ (10)). Taken together, the results provide further evidence for particlemediated biological responses in lung tissue slices and the feasibility of this application to lung toxicity testing. Although several studies have demonstrated toxicity of ENM in lung tissue slices [41,42], this is the first report to our knowledge to compare responses to different size and types of ENM in both mice and mouse lung tissue slices. In addition, the rank order of ENM IL-6 production from the MH-S cells was the same as that observed in both the ex vivo and in vivo comparisons suggesting that lung macrophages play an important role in this response. In contrast, the response ranking for TNF- $\alpha$ (which is expressed at lower levels in lung macrophages compared to IL-6 [43]) was not the same, suggesting that this biomarker would not be a good readout across the three systems. It should be noted that lung epithelial cells and macrophages differ in pro-inflammatory responses following exposure to ENM $[44,45]$ and that toxicity differs depending on the cell of origin [36], as demonstrated by the observation that cancerous cells are more toxic than their normal precursors.

\section{Conclusions}

We conclude that small-sized ENM, $\mathrm{SiO}_{2}(10)$ and $\mathrm{CeO}_{2}$ (23) but not $\mathrm{TiO}_{2}$ (10), caused acute lung toxicity in mice (in vivo). $\mathrm{CeO}_{2}$ (23) had the strongest effect on cytokine (IL-6, TNF- $\alpha$, and MIP-2) release, neutrophil recruitment, and increased protein into the mouse lungs, while the larger $\mathrm{CeO}_{2}$ (88) and $\mathrm{TiO}_{2}$ (200) were less potent, indicating that the effect was dependent on both size and chemical composition of ENM. The rank order of ENM toxicity from both lung tissue slices (ex vivo) and alveolar macrophages (in vitro) corresponded well to the ranking results from the mice (in vivo), suggesting that lung macrophages could replicate this effect. The similar profile of inflammatory response ex vivo and in vitro was most apparent when the exposure was based on mass per cell surface area. Although we demonstrated a relatively good correlation among the acute lung toxicity endpoints from three different testing methods, further studies are still needed that measure reversibility of effects or progression to long term toxicity. Nevertheless the results provide further evidence for the feasibility of replacing animal lung toxicity testing with cells or lung tissue slices, and provide information about the important parameters (e.g., agglomeration state and exposure dose metric) that will improve interpretation of ENM toxicity in biological systems.

\section{Materials and methods}

Experimental animals

Adult pathogen-free female CD-1 mice ( 20-25 g and $\sim 30$ $45 \mathrm{~g}$ body weights for pulmonary toxicity and lung tissue 
slice studies, respectively) purchased from Charles River Breeding Laboratories (Raleigh, NC). Mice were housed in groups of five in polycarbonate cages with hardwood chip bedding at the U.S. Environmental Protection Agency (EPA) Animal Care Facility accredited by the Association for Assessment and Accreditation of Laboratory Animal Care and were maintained on a 12-hour light to dark cycle at $22.3 \pm 1.1^{\circ} \mathrm{C}$ temperature and $50 \pm 10 \%$ humidity. Mice were given access to rodent chow and water ad libitum and were acclimated for at least 10 days before the study began. The studies were conducted after approval by the EPA Institutional Animal Care and Welfare Committee.

\section{Engineered nanomaterials (ENM)}

Five ENM were used in this study and designated by their mean primary diameter provided by the manufacturer: $\mathrm{SiO}_{2}$ (10) (silicon dioxide with a primary diameter of 5-15 nm; amorphous; Sigma Aldrich (St. Louis, MO)), $\mathrm{CeO}_{2}$ (23) (cerium oxide with a primary diameter of 15$30 \mathrm{~nm}$; cerianite; NanoAmor (Houston, TX)), $\mathrm{CeO}_{2}$ (88) (cerium oxide with a primary diameter of 70-105 nm; cerianite; Alfa Aesar (Ward Hill, MA)), $\mathrm{TiO}_{2}$ (10) (titanium dioxide with a primary diameter of $10 \mathrm{~nm}$; anatase; Alfa Aesar), and $\mathrm{TiO}_{2}$ (200) (titanium dioxide with a primary diameter of $200 \mathrm{~nm}$; anatase; Acros Organics (Fair Lawn, $\mathrm{NJ})$ ). The ENM were suspended in saline for in vivo and culture media (see below for further details) for ex vivo and in vitro, followed by sonication (Sonicator 4000; Misonix Sonicators, Newtown, CT) at 70-80 watts for $10 \mathrm{~min}$ and vortex mixing for $1 \mathrm{~min}$ to yield a stock solution at a concentration of $2 \mathrm{mg} / \mathrm{mL}$. The ENM suspensions were stored at $-80^{\circ} \mathrm{C}$ until toxicity testing. To explore the effect of solution chemistry on hydrodynamic diameters of ENM, dynamic light scattering (Zetasizer Nano ZS; Malvern Instruments, Malvern, UK) was used at $100 \mu \mathrm{g} / \mathrm{mL}$ ENM concentration in various solutions, such as distilled water, saline, and culture media. Further detailed physicochemical characteristics of ENM are presented in Table 1.

\section{In vivo toxicity of ENM \\ Mouse exposure to ENM}

Oropharyngeal aspiration was performed on mice anesthetized in a small plexiglass box using vaporized anesthetic isofluorane, following a technique described previously [46]. Briefly, the tongue of the mouse was extended with forceps and $100 \mu \mathrm{g}$ of ENM in $50 \mu \mathrm{L}$ saline was pipetted into the oropharynx. Immediately, the nose of the mouse was then covered causing the liquid to be aspirated into the lungs. Similarly, a separate group of mice was instilled with $2 \mu \mathrm{g}$ of lipopolysaccharide (LPS; Escherichia coli endotoxin; 011:B4 containing $10^{6}$ unit/mg material; Sigma) as a positive control to demonstrate maximal responsiveness to this well characterized inflammatory agent while additional mice were instilled with $50 \mu \mathrm{L}$ saline alone as a negative control.

\section{Bronchoalveolar lavage and hematology}

At $4 \mathrm{hr}$ and $24 \mathrm{hr}$ post-exposure, six mice from each treatment group were euthanized with $0.1 \mathrm{~mL}$ intraperitoneal injection of Euthasol (diluted 1:10 in saline; $390 \mathrm{mg}$ pentobarbital sodium and $50 \mathrm{mg}$ phenytoin/mL; Virbac AH, Inc., Fort Worth, TX), and blood was collected by cardiac puncture using a 1-mL syringe containing $17 \mu \mathrm{L}$ sodium citrate to prevent coagulation. The trachea was then exposed, cannulated and secured with suture thread. The thorax was opened and the left mainstem bronchus was isolated and clamped with a microhemostat. The right lung lobes were lavaged three times with a single volume of warmed Hanks balanced salt solution (HBSS; $35 \mathrm{~mL} / \mathrm{kg}$ mouse). The recovered bronchoalveolar lavage fluid (BALF) was centrifuged at $800 \mathrm{xg}$ for $10 \mathrm{~min}$ at $4^{\circ} \mathrm{C}$ and the supernatant was stored at both $4^{\circ} \mathrm{C}$ (for biochemical analysis) and $-80^{\circ} \mathrm{C}$ (for cytokine analysis). The pelleted cells were resuspended in $1 \mathrm{~mL}$ HBSS (Sigma). Total BALF cell count of each mouse was obtained by a Coulter counter (Coulter Co., Miami, FL). Additionally, $200 \mu \mathrm{L}$ resuspended cells were centrifuged in duplicate onto slides using a Cytospin (Shandon, Pittsburgh, PA) and subsequently stained with Diff-Quik solution (American Scientific Products, McGraw Park, PA) for enumeration of macrophages and neutrophils with at least 200 cells counted from each slide. Hematology values including total white blood cells, total red blood cells, hemoglobin, hematocrit, mean corpuscular volume, mean corpuscular hemoglobin concentration, and platelets were measured using a Coulter AcT 10 Hematology Analyzer (Beckman Coulter Inc., Miami, FL).

\section{Biochemical and cytokine analyses}

Concentrations of lactate dehydrogenase (LDH) and $\gamma$ glutamyl transferase (GGT) were determined using commercially available kits (Thermo Scientific, Middletown, VA). Albumin and total protein concentrations were measured by the SPQ test system (DiaSorin, Stillwater, $\mathrm{MN}$ ) and the Coomassie plus protein assay (Pierce Chemical, Rockford, IL) with a standard curve prepared with bovine serum albumin (Sigma), respectively. Activity of N-acetyl- $\beta$-D-glucoaminidase (NAG) was determined using a NAG assay kit (Roche Applied Science, Indianapolis, IN). All biochemical assays were modified for use on the KONELAB 30 clinical chemistry spectrophotometer analyzer (Thermo Clinical Lab Systems, Espoo, Finland) as described previously [46]. Concentrations of tumor necrosis factor- $\alpha$ (TNF- $\alpha$ ), interleukin-6 (IL-6) and macrophage inhibitory protein-2 (MIP-2) in BALF were determined using commercial multiplexed fluorescent bead-based immunoassays (Milliplex Map Kit, Millpore 
Co., Billerica, MA) measured by a Luminex 100 (Luminex Co., Austin, TX) following the manufacturer's protocol. The limits of detection (LOD) of each cytokine were 6.27, 3.28 and $29.14 \mathrm{pg} / \mathrm{mL}$ for TNF- $\alpha$, IL- 6 and MIP-2, respectively, and all values below these lowest values were replaced with a fixed value of one-half of the LOD value.

\section{Ex vivo toxicity of ENM \\ Mouse lung tissue slice preparation and incubation}

Lung tissue slices were prepared as previously described [40]. Briefly, mice were euthanized with $0.1 \mathrm{~mL}$ intraperitoneal injection of Euthasol (diluted 1:10 in saline; Virbac $\mathrm{AH}$, Inc.). The trachea was exposed and cannulated using a 20G luer stub adapter (Instech Solomon, Plymouth Meeting, PA). The lungs were filled with $1.5 \%(\mathrm{w} / \mathrm{v})$ low-melting agarose (Sigma) in minimum essential medium (MEM; Simga) at $37^{\circ} \mathrm{C}$. The lungs were rinsed with the ice-cold slicing buffer solution (Earle's balanced salt solution (Sigma) supplemented with $15 \mathrm{mM} \mathrm{N}$-(2-hydroxyethyl)piperazine$\mathrm{N}^{\prime}$-(2-ethanesulfonic acid) hemisodium salt (HEPES; Sigma)) and removed from the mouse. The lungs were transferred into the ice-cold slicing buffer solution to further solidify the agarose and then the lung lobes were separated using a surgical blade, and the lung tissue cores (8 $\mathrm{mm}$ diameter) were prepared using a tissue coring tool (Alabama Research and Development, Munford, AL). Tissue cores were cut into $350 \mu \mathrm{m}$ thick slices in the ice-cold slicing buffer solution using a specialized vibratome (OTS 5000, FHC Inc., Bowdoinham, ME). The lung tissue slices were then incubated in the wash buffer solution (Dulbecco's modified eagle's medium/nutrient mixture F-12 Ham (Sigma) supplemented with 100 units $/ \mathrm{mL}$ penicillin (Sigma) and $100 \mu \mathrm{g} / \mathrm{mL}$ streptomycin (Sigma)) under cell culture conditions for 4 hrs. The lung tissue slices were then transferred into a tissue culture treated polystyrene 48-well plate (Corning Inc., Corning, NY) and cultured in the slice incubation medium (the wash buffer solution supplemented with $200 \mathrm{mM} \mathrm{L}$-glutamine (Sigma), $0.1 \mathrm{mM}$ MEM non-essential amino acids (Sigma) and $15 \mathrm{mM}$ HEPES) for up to 6 days at $37^{\circ} \mathrm{C}$ in a humidified atmosphere of $5 \% \mathrm{CO}_{2}$ and $95 \%$ air. The lung tissue slices received fresh media every day.

\section{Mouse lung tissue slice exposure to ENM}

Reconstituted ENM suspensions were sonicated for $2 \mathrm{~min}$, vortexed for $1 \mathrm{~min}$ and further diluted with the slice incubation medium to achieve final concentrations of 22, 44, 66 , and $132 \mu \mathrm{g} / \mathrm{mL}$. On day 2 of culture, lung tissue slices were exposed to the ENM for $24 \mathrm{hrs}$. The initial concentration of $22 \mu \mathrm{g} / \mathrm{mL}$ (total volume of $0.5 \mathrm{~mL}$, therefore of $11 \mu \mathrm{g}$ of ENM per lung slice) was estimated to be five times higher than the in vivo exposure dose used in this study. If it is assumed that the lung surface area of a $20 \mathrm{~g}$ mouse is $\sim 650 \mathrm{~cm}^{2}, 1 \mathrm{~cm}^{3}$ mouse lung tissue has $\sim 800 \mathrm{~cm}^{2}$ lung surface area, and $100 \%$ of oropharyngeal instilled ENM is delivered to the lungs, $100 \mu \mathrm{g}$ of ENM dose in a mouse $\left(\sim 650 \mathrm{~cm}^{2}\right.$ lung surface area) is equivalent to $2.2 \mu \mathrm{g}$ of ENM dose in a mouse lung slice $\left(\sim 14 \mathrm{~cm}^{2}\right.$ lung slice surface area) [47]. Moreover, if it is assumed that the lung slice surface area is $\sim 14 \mathrm{~cm}^{2}$, the exposure doses of $22,44,66$, and $132 \mu \mathrm{g} / \mathrm{mL}$ are equivalent to the doses of $0.79,1.6,2.3$, and $4.7 \mu \mathrm{g} / \mathrm{cm}^{2}$, respectively. Mouse lung tissue slices were exposed to $87 \mathrm{ng} / \mathrm{mL}$ LPS which was an equivalent concentration in vivo and served as a positive control. Mouse lung tissue slices exposed to the culture medium alone served as a negative control. At $24 \mathrm{hr}$ post-exposure, lung slice culture fluids were collected, centrifuged at 10,000xg for $5 \mathrm{~min}$, and culture supernatants were stored at both $4^{\circ} \mathrm{C}$ (for extracellular biochemical analysis) and $-80^{\circ} \mathrm{C}$ (for cytokine analysis). Subsequently, mouse lung tissue slices were homogenized using a tissue homogenizer in a lysis buffer solution containing $0.5 \%$ Triton X-100, $150 \mathrm{mM} \mathrm{NaCl}$, $15 \mathrm{mM}$ Tris- $\mathrm{HCl}$ (pH 7.4), $1 \mathrm{mM} \mathrm{CaCl}$ and $1 \mathrm{mM}$ $\mathrm{MgCl}_{2}$ [48]. Homogenates were then centrifuged at $10,000 \times \mathrm{g}$ for $10 \mathrm{~min}$ and supernatants were stored at $-80^{\circ} \mathrm{C}$ (for intracellular biochemical analysis).

\section{Biochemical and cytokine analyses}

Similar to the in vivo lung inflammation analyses described above, the supernatants of tissue culture fluids and tissue homogenates after exposure to ENM were used to determine the extracellular (LDH and NAG) and intracellular (GGT) biochemical analyses as well as cytokine analysis (IL-6, MIP-2, and TNF- $\alpha$ ). Biochemical and proinflammatory cytokine analyses were performed using a KONELAB 30 clinical chemistry spectrophotometer analyzer (Thermo Clinical Lab Systems) and multiplexed fluorescent bead-based immunoassays (Milliplex Map Kit) measured by the Luminex 100 (Luminex Co).

\section{In vitro toxicity of ENM \\ Alveolar macrophage cell culture}

The murine alveolar macrophages (MH-S) cells were purchased from ATCC (CRL2019, Manassas, VA) and grown in the following culture medium: RPMI 1640 (Sigma) supplemented with $5 \%$ fetal bovine albumin (FBS; Sigma) and 100 units/mL penicillin (Sigma) and $100 \mu \mathrm{g} / \mathrm{mL}$ streptomycin (Sigma) at $37^{\circ} \mathrm{C}$ in a humidified atmosphere of $5 \%$ $\mathrm{CO}_{2}$ and $95 \%$ air. MH-S cells at passage 11 yielded 2.4 $2.9 \times 10^{6}$ cells $/ \mathrm{mL}$ and were seeded at 3,000 cells per well of a 96-well culture plate.

\section{Alveolar macrophage cell exposure to ENM}

After 3 days in culture, MH-S cells were exposed to ENM at final concentrations of 3.125, 6.25, 12.5, 25, 50, and $100 \mu \mathrm{g} / \mathrm{mL}$ in the culture medium for $24 \mathrm{hrs}$. This exposure dose can be converted to the dose based on 
cell surface area (assuming MH-S cell surface area is $0.3 \mathrm{~cm}^{2}$ ). Thus, the exposure doses of $3.125,6.25,12.5$, 25,50 , and $100 \mu \mathrm{g} / \mathrm{mL}$ are equivalent to the doses of 1.0 , $2.1,4.2,8.3,16.7$, and $33.3 \mu \mathrm{g} / \mathrm{cm}^{2}$, respectively. MH-S cells exposed to the culture medium alone served as a negative control and $1 \%$ Triton $\mathrm{X}-100$ at $37^{\circ} \mathrm{C}$ served as a positive control.

\section{Biochemical and cytokine analyses}

After the cells exposed to ENM, the plate was centrifuged at $400 \mathrm{xg}$ for $5 \mathrm{~min}$, followed by collection of supernatants to analyze LDH concentrations. The supernatants were also used to determine cytokine production (IL-6). The $\mathrm{MH}-\mathrm{S}$ cells after centrifugation were then used to evaluate cell proliferation (CyQuant assay; Invitrogen, Eugene, OR). Viability of the MH-S cells exposed to ENM was tested by measuring enzymatic activity based on the cellular cleavage of water-soluble tetrazolium salt (WST-1) to formazan in the cells using a WST-1 assay kit (Roche Applied Science). Biochemical and pro-inflammatory cytokine analyses in this study were also performed using a KONELAB 30 clinical chemistry spectrophotometer analyzer (Thermo Clinical Lab Systems) and multiplexed fluorescent bead-based immunoassays (Milliplex Map Kit) measured by the Luminex 100 (Luminex Co).

\section{Statistical analysis}

Data were expressed as means \pm the standard error of the mean (SEM). The results of the ENM-exposed groups were compared to those of the negative control group. Statistical comparison was performed by one-way analysis of variance (ANOVA) with the Newman-Keuls post-hoc test. Statistical analyses were performed using commercial software (GraphPad Prism 6.04, GraphPad Software, Inc., San Diego, CA). If the data did not meet the ANOVA assumptions of either normality or equal variances (Levene's test; $p>0.05$ ), the data were transformed. Subsequent to the transformation, the data were checked for requirement compliance and if acceptable, ANOVA proceeded. The statistical significance level was assigned at a probability value of $p<0.05$.

\section{Additional files}

Additional file 1: Figure S1. Representative BAL cell images at $4 \mathrm{hr}$ and $24 \mathrm{hr}$ post-exposure to ENM. Red arrows indicate ENP uptakes in alveolar macrophages. Original magnification (20x), inset (40x).

Additional file 2: Figure $\mathbf{S 2}$. Dose-response curves to determine $\mathrm{EC}_{50}$ values for the MH-S cells from WST-1 assay data.

\section{Abbreviations}

ANOVA: Analysis of variance; BALF: Bronchoalveolar lavage fluid; $\mathrm{CeO}_{2}$ (23): Cerium oxide with a primary diameter of $15-30 \mathrm{~nm} ; \mathrm{CeO}_{2}$ (88): Cerium oxide with a primary diameter of 70-105 nm; CM: Culture medium; $\mathrm{EC}_{50}$ : Half-maximal effective concentrations; ENM: Engineered nanomaterials; GGT: $\gamma$-glutamyl transferase; HBSS: Hanks balanced salt solution; HEPES: N-(2-
hydroxyethyl)piperazine-N'-(2-ethanesulfonic acid) hemisodium salt; IL6: Interleukin-6; LDH: Lactate dehydrogenase; LPS: Lipopolysaccharide; MEM: Minimum essential medium; MIP-2: Macrophage inhibitory protein-2; NAG: N-acetyl- $\beta$-D-glucoaminidase; RBC: Red blood cells; SEM: Standard error of the mean; $\mathrm{SiO}_{2}$ (10): Silicon dioxide with a primary diameter of 5-15 nm; $\mathrm{TiO}_{2}$ (10): Titanium dioxide with a primary diameter of $10 \mathrm{~nm} ; \mathrm{TiO}_{2}$ (200): Titanium dioxide with a primary diameter of $200 \mathrm{~nm}$; TNF-a: Tumor necrosis factor-a; WST-1: Water-soluble tetrazolium salt.

\section{Competing interests}

The authors declare that they have no competing interests.

\section{Authors' contributions}

YHK contributed to the experimental design, carried out the pulmonary assessment and lung tissue slice experiment, performed the data analyses and figure generations, and drafted the manuscript. EB performed the pulmonary assessment and helped with data analyses. TS performed the $\mathrm{MH}-\mathrm{S}$ cell experiment. $\mathrm{KL}$ assisted with the experimental design and pulmonary assessment. MIG conceived and designed the experiment, evaluated the results, and co-wrote the manuscript. All of the authors read and approved the final manuscript.

\section{Acknowledgements}

We thank Debora Andrews, Judy Richards, and Richard Jaskot for technical assistance in toxicologic analyses and Drs. Kevin Dreher and James Samet for their review of this manuscript. The project was supported by grant from the EPA-UNC Toxicology Training Agreement (CR-83515201-0), with the Curriculum in Toxicology, University of North Carolina at Chapel Hill. This paper has been reviewed by the National Health and Environmental Effects Research Laboratory, U.S. Environmental Protection Agency, and approved for publication. Approval does not signify that contents necessarily reflect the views and polices of Agency, nor does the mention of trade names or commercial products constitute endorsement or recommendation for use.

\section{Author details}

${ }^{1}$ Curriculum in Toxicology, University of North Carolina at Chapel Hill, Chapel Hill, NC, USA. ${ }^{2}$ Environmental Public Health Division, National Health and Environmental Effects Research Laboratory, United States Environmental Protection Agency, Research Triangle Park, NC, USA. ${ }^{3}$ Research Triangle Park Division, National Center for Environmental Assessment, United States Environmental Protection Agency, Research Triangle Park, NC, USA.

Received: 5 August 2014 Accepted: 23 October 2014

Published online: 26 November 2014

\section{References}

1. Jud C, Clift MJ, Petri-Fink A, Rothen-Rutishauser B: Nanomaterials and the human lung: what is known and what must be deciphered to realise their potential advantages? Swiss Med Wkly 2013, 143:W13758.

2. Maynard AD, Aitken RJ, Butz T, Colvin V, Donaldson K, Oberdorster G, Philbert MA, Ryan J, Seaton A, Stone V, Tinkle SS, Tran L, Walker NJ, Warheit DB: Safe handling of nanotechnology. Nature 2006, 444(7117):267-269.

3. Hubbs AF, Mercer RR, Benkovic SA, Harkema J, Sriram K, Schwegler-Berry D, Goravanahally MP, Nurkiewicz TR, Castranova V, Sargent LM: Nanotoxicology-a pathologist's perspective. Toxicol Pathol 2011, 39(2):301-324.

4. Kreyling W, Semmler-Behnke M, Möller W: Health implications of nanoparticles. J Nanoparticle Res 2006, 8(5):543-562.

5. Madl AK, Pinkerton KE: Health effects of inhaled engineered and incidental nanoparticles. Crit Rev Toxicol 2009, 39(8):629-658.

6. Oberdorster G, Oberdorster E, Oberdorster J: Nanotoxicology: an emerging discipline evolving from studies of ultrafine particles. Environ Health Perspect 2005, 113(7):823-839.

7. Phillips Jl, Green FY, Davies JC, Murray J: Pulmonary and systemic toxicity following exposure to nickel nanoparticles. Am J Ind Med 2010, 53(8):763-767.

8. Hendren CO, Mesnard X, Dröge J, Wiesner MR: Estimating production data for five engineered nanomaterials as a basis for exposure assessment. Environ Sci Technol 2011, 45(7):2562-2569.

9. Cassee FR, van Balen EC, Singh C, Green D, Muijser H, Weinstein J, Dreher K: Exposure, health and ecological effects review of engineered nanoscale 
cerium and cerium oxide associated with its use as a fuel additive. Crit Rev Toxicol 2011, 41(3):213-229.

10. Shi H, Magaye $R$, Castranova V, Zhao J: Titanium dioxide nanoparticles: a review of current toxicological data. Part Fibre Toxicol 2013, 10:15.

11. Chen J, Patil S, Seal S, McGinnis JF: Rare earth nanoparticles prevent retinal degeneration induced by intracellular peroxides. Nat Nanotechnol 2006, 1(2):142-150

12. Korsvik C, Patil S, Seal S, Self WT: Superoxide dismutase mimetic properties exhibited by vacancy engineered ceria nanoparticles. Chem Commun 2007, 10:1056-1058.

13. Tang $L$, Cheng J: Nonporous silica nanoparticles for nanomedicine application. Nano Today 2013, 8(3):290-312.

14. Hiraiwa K, van Eeden SF: Contribution of lung macrophages to the inflammatory responses induced by exposure to air pollutants. Mediators Inflamm 2013, 2013:619523.

15. Sanders K, Degn LL, Mundy WR, Zucker RM, Dreher K, Zhao B, Roberts JE, Boyes WK: In vitro phototoxicity and hazard identification of nano-scale titanium dioxide. Toxicol Appl Pharmacol 2012, 258(2):226-236.

16. Haynes WM: CRC Handbook of Chemistry and Physics. 94th edition. Boca Raton, FL: CRC Press/Taylor \& Francis Group; 2013.

17. DeLoid G, Cohen JM, Darrah T, Derk R, Rojanasakul L, Pyrgiotakis G, Wohlleben W, Demokritou P: Estimating the effective density of engineered nanomaterials for in vitro dosimetry. Nat Commun 2014, 5:3514.

18. Cohen JM, Teeguarden JG, Demokritou P: An integrated approach for the in vitro dosimetry of engineered nanomaterials. Part Fibre Toxicol 2014 $11: 20$.

19. Sterling MC Jr, Bonner JS, Ernest AN, Page CA, Autenrieth RL: Application of fractal flocculation and vertical transport model to aquatic sol-sediment systems. Water Res 2005, 39(9):1818-1830.

20. Hinderliter PM, Minard KR, Orr G, Chrisler WB, Thrall BD, Pounds JG, Teeguarden JG: ISDD: a computational model of particle sedimentation, diffusion and target cell dosimetry for in vitro toxicity studies. Part Fibre Toxicol 2010, 7(1):36.

21. Diaz B, Sanchez-Espinel C, Arruebo M, Faro J, de Miguel E, Magadan S, Yague C, Fernandez-Pacheco R, Ibarra MR, Santamaria J, Gonzalez-Fernandez A: Assessing methods for blood cell cytotoxic responses to inorganic nanoparticles and nanoparticle aggregates. Small 2008, 4(11):2025-2034.

22. Fazlollahi F, Kim YH, Sipos A, Hamm-Alvarez SF, Borok Z, Kim KJ, Crandall ED: Nanoparticle translocation across mouse alveolar epithelial cell monolayers: species-specific mechanisms. Nanomedicine 2013, 9(6):786-794.

23. Brunner TJ, Wick P, Manser P, Spohn P, Grass RN, Limbach LK, Bruinink A, Stark WJ: In vitro cytotoxicity of oxide nanoparticles: comparison to asbestos, silica, and the effect of particle solubility. Environ Sci Technol 2006, 40(14):4374-4381.

24. Kim YH, Fazlollahi F, Kennedy IM, Yacobi NR, Hamm-Alvarez SF, Borok Z, Kim $\mathrm{KJ}$, Crandall ED: Alveolar epithelial cell injury due to zinc oxide nanoparticle exposure. Am J Respir Crit Care Med 2010, 182(11):1398-1409.

25. Xia T, Kovochich M, Liong M, Madler L, Gilbert B, Shi H, Yeh Jl, Zink Jl, Nel AE: Comparison of the mechanism of toxicity of zinc oxide and cerium oxide nanoparticles based on dissolution and oxidative stress properties. ACS Nano 2008, 2(10):2121-2134.

26. Napierska D, Thomassen LC, Lison D, Martens JA, Hoet PH: The nanosilica hazard: another variable entity. Part Fibre Toxicol 2010, 7(1):39.

27. Zhang H, Ji Z, Xia T, Meng H, Low-Kam C, Liu R, Pokhrel S, Lin S, Wang X, Liao YP, Wang M, Li L, Rallo R, Damoiseaux R, Telesca D, Madler L, Cohen Y Zink J, Nel AE: Use of metal oxide nanoparticle band gap to develop a predictive paradigm for oxidative stress and acute pulmonary inflammation. ACS Nano 2012, 6(5):4349-4368

28. Cho WS, Choi M, Han BS, Cho M, Oh J, Park K, Kim SJ, Kim SH, Jeong J: Inflammatory mediators induced by intratracheal instillation of ultrafine amorphous silica particles. Toxicol Lett 2007, 175(1-3):24-33.

29. Aalapati S, Ganapathy S, Manapuram S, Anumolu G, Prakya BM: Toxicity and bio-accumulation of inhaled cerium oxide nanoparticles in CD1 mice. Nanotoxicology 2014, 8(7):786-798.

30. Ma JY, Zhao H, Mercer RR, Barger M, Rao M, Meighan T, Schwegler-Berry D, Castranova V, Ma JK: Cerium oxide nanoparticle-induced pulmonary inflammation and alveolar macrophage functional change in rats. Nanotoxicology 2011, 5(3):312-325.

31. Srinivas A, Rao PJ, Selvam G, Murthy PB, Reddy PN: Acute inhalation toxicity of cerium oxide nanoparticles in rats. Toxicol Lett 2011, 205(2):105-115.
32. Gosens I, Mathijssen LE, Bokkers BG, Muijser H, Cassee FR: Comparative hazard identification of nano- and micro-sized cerium oxide particles based on 28-day inhalation studies in rats. Nanotoxicology 2014, 8(6):643-653.

33. McDonald JW, Ghio AJ, Sheehan CE, Bernhardt PF, Roggli VL: Rare earth (cerium oxide) pneumoconiosis: analytical scanning electron microscopy and literature review. Mod Pathol 1995, 8(8):859-865.

34. Vocaturo G, Colombo F, Zanoni M, Rodi F, Sabbioni E, Pietra R: Human exposure to heavy metals. Rare earth pneumoconiosis in occupational workers. Chest 1983, 83(5):780-783.

35. Bonner JC, Silva RM, Taylor AJ, Brown JM, Hilderbrand SC, Castranova V, Porter D, Elder A, Oberdorster G, Harkema JR, Bramble LA, Kavanagh TJ, Botta D, Nel A, Pinkerton KE: Interlaboratory evaluation of rodent pulmonary responses to engineered nanomaterials: the NIEHS Nano GO Consortium. Environ Health Perspect 2013, 121(6):676-682

36. Joris F, Manshian BB, Peynshaert K, De Smedt SC, Braeckmans K, Soenen SJ: Assessing nanoparticle toxicity in cell-based assays: influence of cell culture parameters and optimized models for bridging the in vitro-in vivo gap. Chem Soc Rev 2013, 42(21):8339-8359.

37. Teeguarden JG, Hinderliter PM, Orr G, Thrall BD, Pounds JG: Particokinetics in vitro: dosimetry considerations for in vitro nanoparticle toxicity assessments. Toxicol Sci 2007, 95(2):300-312.

38. Baisch BL, Corson NM, Wade-Mercer P, Gelein R, Kennell AJ, Oberdorster G, Elder A: Equivalent titanium dioxide nanoparticle deposition by intratracheal instillation and whole body inhalation: the effect of dose rate on acute respiratory tract inflammation. Part Fibre Toxicol 2014, 11:5.

39. Rivera-Gil $P$, Jimenez de Aberasturi $D$, Wulf $V$, Pelaz $B$, del Pino $P$, Zhao $Y$, de la Fuente JM, Ruiz de Larramendi I, Rojo T, Liang XJ, Parak WJ: The challenge to relate the physicochemical properties of colloidal nanoparticles to their cytotoxicity. Acc Chem Res 2013, 46(3):743-749.

40. Kim YH, Tong H, Daniels M, Boykin E, Krantz QT, McGee J, Hays M, Kovalcik K, Dye JA, Gilmour Ml: Cardiopulmonary toxicity of peat wildfire partcualte matter and the predictive utility of precision cut lung slices. Part Fibre Toxicol 2014, 11:29.

41. Neuhaus V, Schwarz K, Klee A, Seehase S, Forster C, Pfennig O, Jonigk D, Fieguth HG, Koch W, Warnecke G, Yusibov V, Sewald K, Braun A: Functional testing of an inhalable nanoparticle based influenza vaccine using a human precision cut lung slice technique. PLoS One 2013, 8(8):e71728.

42. Sauer UG, Vogel S, Aumann A, Hess A, Kolle SN, Ma-Hock L, Wohlleben W, Dammann M, Strauss V, Treumann S, Groters S, Wiench K, van Ravenzwaay B, Landsiedel R: Applicability of rat precision-cut lung slices in evaluating nanomaterial cytotoxicity, apoptosis, oxidative stress, and inflammation. Toxicol Appl Pharmacol 2014, 276(1):1-20.

43. Losa Garcia JE, Rodriguez FM, de Cabo MR M, Garcia Salgado MJ, Losada JP, Villaron LG, Lopez AJ, Arellano JL: Evaluation of inflammatory cytokine secretion by human alveolar macrophages. Mediators Inflamm 1999, 8(1):43-51.

44. Sayes C, Reed K, Subramoney S, Abrams L, Warheit D: Can in vitro assays substitute for in vivo studies in assessing the pulmonary hazards of fine and nanoscale materials? J Nanoparticle Res 2009, 11(2):421-431.

45. Sayes CM, Reed KL, Warheit DB: Assessing toxicity of fine and nanoparticles: comparing in vitro measurements to in vivo pulmonary toxicity profiles. Toxicol Sci 2007, 97(1):163-180.

46. Gilmour MI, McGee J, Duvall RM, Dailey L, Daniels M, Boykin E, Cho SH, Doerfler D, Gordon T, Devlin RB: Comparative toxicity of size-fractionated airborne particulate matter obtained from different cities in the United States. Inhal Toxicol 2007, 19(Suppl 1):7-16.

47. Schmidt-Nielsen K: Animal Physiology: Adaptation and Environment. 5th edition. Cambridge, UK: Cambridge University Press; 1997.

48. Whitehead GS, Grasman KA, Kimmel EC: Lung function and airway inflammation in rats following exposure to combustion products of carbon-graphite/epoxy composite material: comparison to a rodent model of acute lung injury. Toxicology 2003, 183(1-3):175-197.

\section{doi:10.1186/s12951-014-0047-3}

Cite this article as: Kim et al:: Comparative lung toxicity of engineered nanomaterials utilizing in vitro, ex vivo and in vivo approaches. Journal of Nanobiotechnology 2014 12:47. 